JURNAL TERKNOSAINS

VOLUME 2

No. 1, 22 Desember 2012

Halaman 1-70

\title{
IDENTIFIKASI EFEK DEPRESAN SSP (SUSUNAN SARAF PUSAT), ANTIKEJANG DAN NEUROTOKSISITAS SENYAWA 4-KLOROBENZOILTIOUREA PADA MENCIT PUTIH JANTAN
}

\author{
Aguslina Kirtishanti dan Dini Kesuma \\ Fakultas Farmasi Universitas Surabaya \\ Email: sc_kirtishanti@yahoo.co.id
}

\begin{abstract}
The study of benzoylthiourea derivatives development as central nervous system (CNS) depressants were based on its structure which contains acyclic ureida group, an isosteric group of CNS depressant drugs common structure. The study approach is taken by modifying the structure of benzoylthiourea using Topliss model based on the enhancement of lipophilic and electronic properties, and the product is predicted to give higher activity than the parent compound.

Identification of CNS depressant, anticonvulsant and neurotoxicity effects of the compound synthesized, 4-chlorobenzoylthiourea, was conducted. Identification of CNS depressant effects was done using Barbiturate Sleeping Time, while identification of anticonvulsant effects was done using Maximum Electroshock Seizure and neurotoxicity effect using rotarod in mice (Mus musculus). This study used five groups of mice: a control group, a standard group (Phenobarbital $\mathrm{Na}$ ) and 3 treatment groups with the doses of $15 \mathrm{mg} / \mathrm{kg}, 45 \mathrm{mg} / \mathrm{kg}$ and $75 \mathrm{mg} /$ $\mathrm{kg}$ respectively. From the results, it can be concluded that 4-chlorobenzoylthiourea gives the best CNS depressant, anticonoulsant, and neurotoxicity effects at the doses of $75 \mathrm{mg} / \mathrm{kg}, 15 \mathrm{mg} / \mathrm{kg}$, and $45 \mathrm{mg} / \mathrm{kg}$ respectively.
\end{abstract}

Keywords: CNS depressant effect, anticonvulsant, neurotoxicity, 4-chlorobenzoylthiourea, Barbiturate Sleeping Time, Electroshock Seizure, Rotarod 


\title{
IDENTIFIKASI EFEK DEPRESAN SSP (SUSUNAN SARAF PUSAT), ANTIKEJANG DAN NEUROTOKSISITAS SENYAWA 4-KLOROBENZOILTIOUREA PADA MENCIT PUTIH JANTAN
}

\author{
Aguslina Kirtishanti dan Dini Kesuma \\ Fakultas Farmasi Universitas Surabaya \\ Email: sc_kirtishanti@yahoo.co.id
}

\begin{abstract}
ABSTRAK
Pengembangan senyawa turunan benzoiltiourea sebagai penekan sistem saraf pusat (SSP), didasarkan pada struktur senyawa yang mengandung gugus ureida asiklik yang merupakan isosterik dari struktur obat penekan SSP pada umumnya. Pendekatan yang dilakukan adalah dengan melakukan modifikasi struktur benzoiltiourea menggunakan model Topliss, berdasarkan perubahan sifat lipofilik dan elektronik yang makin meningkat, diramalkan dapat memberikan aktivitas yang lebih tinggi dibandingkan senyawa induk.

Pada pengamatan ini dilakukan identifikasi efek depresan SSP, antikejang, dan neurotoksisitas dari senyawa hasil sintesis yaitu 4-klorobenzoiltiourea. Identifikasi efek depresan SSP menggunakan metode Barbiturat Sleeping Time, identifikasi efek antikejang dengan menggunakan metode Maximum Electroshock Seizure, dan efek neurotoksisitas menggunakan batang berputar (rotarod) pada mencit (Mus musculus). Penelitian ini menggunakan 5 kelompok hewan coba yaitu 1 kelompok kontrol, 1 kelompok pembanding (Phenobarbital Na), dan 3 kelompok uji dengan dosis $15 \mathrm{mg} / \mathrm{kgBB}, 45 \mathrm{mg} / \mathrm{kgBB}$, dan 75 $\mathrm{mg} / \mathrm{kgBB}$. Hasil penelitian ini dapat disimpulkan bahwa senyawa 4-klorobenzoiltiourea memberikan efek depresan SSP, antikejang, dan neurotoksisitas dengan dosis paling baik berturut-turut $75 \mathrm{mg} / \mathrm{kg}$ $\mathrm{BB}, 15 \mathrm{mg} / \mathrm{kg} \mathrm{BB}$, dan $45 \mathrm{mg} / \mathrm{kg}$ BB.
\end{abstract}

Kata Kunci: efek depresan SSP, antikejang, neurotoksisitas, senyawa 4- klorobenzoiltiourea, Barbiturat Sleeping Time, Electroshock Seizure, Rotarod 
AGUSLINA KIRTISHANTI, DINI KESUMA *IDENTIFIKASI EFEK DEPRESAN SSP (SUSUNAN SARAF PUSAT), ANTIKEJANG DAN NEUROTOKSISITAS SENYAWA 4-KLOROBENZOILTIOUREA ...

\section{PENGANTAR}

Manifestasi daristres berupa keluhanfisik atau gangguan fisik, kecemasan tak rasional dan perilaku menghindar, gangguan efek (depresi, iritabilitas), perubahan kesadaran, dan perilaku motorik (Mutschler, 1991). Untuk mengatasi hal tersebut, diperlukan zat-zat yang bekerja pada sistem saraf pusat (SSP), terutama sebagai penekan sistem saraf pusat. Berdasarkan efek farmakologinya, penekan sistem saraf pusat dibagi menjadi lima golongan, yaitu anestesi sistemik, sedatif-hipnotik, relaksan pusat, antipsikotik, dan antikejang (Siswandono dan Soekardjo, 2000).

Untuk mendapatkan obat penekan sistem saraf pusat yang memberikan aktivitas farmakologis yang optimal, perlu dilakukan penelitian lebih lanjut. Penelitian dilakukan dengan mengembangkan struktur senyawa obat yang sudah ada dan mendapatkan obat baru melalui modifikasi struktur molekul dan sintesis analog senyawa induk. Pada tahun 1998, Siswandono telah melakukan sintesis benzoilurea melalui reaksi asilasi antara salah satu gugus amina primer urea dengan gugus benzoil dari benzoil klorida dan telah melakukan penelitian hubungan kuantitatif struktur-aktivitas turunan benzoilurea. Penelitian tersebut mendapatkan hasil bahwa ada hubungan non-linier (parabolik) antara perubahan struktur, parameter sifat-sifat lipofilik $(\log P)$, elektronik $(\delta)$, dan sterik (Es) dari senyawa-senyawa turunan benzoilurea dengan aktivitas pada sistem saraf pusat berupa gangguan koordinasi gerak pada mencit.

Kesuma (2004) melakukan sintesis senyawa benzoiltiourea dengan mengganti atom oksigen pada posisi $\mathrm{C}_{2}$ dengan atom sulfur yang terdapat pada tiourea. Penggantian atom $\mathrm{O}$ pada urea dengan atom $S$ menjadi tiourea, di mana sifat elektronegativitas atom $\mathrm{O}$ lebih besar dari atom $S$, dan diharapkan meningkatkan lipofilitas senyawa benzoiltiourea. Hasil uji aktivitas menunjukkan bahwa senyawa benzoiltiourea tersebut mempunyai efek sebagai penekan sistem saraf pusat, sehingga benzoiltiourea dapat dijadikan sebagai senyawa induk untuk dikembangkan lebih lanjut dalam usaha mendapatkan senyawa baru dengan aktivitas penekan saraf pusat yang lebih tinggi (Kesuma, 2004).

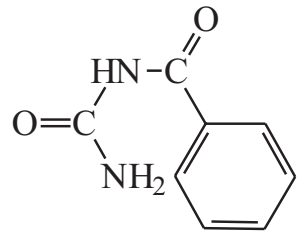

Benzoilurea<smiles>NC(=S)NC(=O)c1ccccc1</smiles>

Benzoiltiourea
Gambar 1. Struktur Benzoilurea dan Benzoiltiourea

Senyawa 4-klorobenzoiltiourea diperoleh dengan memodifikasi struktur benzoiltiourea yang ditambah dengan subtituen 4-kloro dengan cara asilasi tiourea dengan 4-klorobenzoil klorida. Dengan memasukkan atom $\mathrm{Cl}$ pada posisi para akan meningkatkan sifat lipofilik senyawa $(\log \mathrm{P}=1,68)$ dibanding senyawa induk benzoiltiourea dengan $\log \mathrm{P}$ $=1,12$. Dengan meningkatnya sifat lipofilitas senyawa diharapkan akan meningkat pula aktivitas penekan sistem saraf pusat (Kesuma, 2004). Peningkatan sifat lipofilik menyebabkan absorpsi obat melalui membran biologis akan meningkat sehingga memungkinkan banyaknya senyawa yang akan berinteraksi dengan reseptor dan diharapkan akan memperbesar aktivitas penekan SSP (Basuki, 2006).

Selanjutnya senyawa 4-klorobenzoiltiourea dilakukan uji aktivitas penekan SSP pada mencit galur Balb $\mathrm{C}$ dengan tujuan untuk mengetahui efek depresan SSP, efek antikejang, dan efek neurotoksisitas dan dosis berapa yang lebih efektif sebagai penekan SSP. Diharapkan dari penelitian ini akan ditemukan senyawa baru yang mempunyai aktivitas penekan SSP lebih tinggi dibanding benzoiltiourea. 


\section{Bahan dan Alat}

Pengamatan ini merupakan penelitian eksperimental laboratoris dengan melakukan uji aktivitas farmakologis berupa efek depressan SSP menggunakan metode Barbiturat Sleeping Time, antikejang dengan metode Maximum Electroshock Seizure dan neurotoksisitas dengan metode batang berputar (rotarod) terhadap senyawa 4-klorobenzoiltiourea.

4-klorobenzoiltiourea (hasil sintesis) sebagai bahan uji, CMC $\mathrm{Na}$ sebagai suspending agent untuk mensuspensikan 4-klorobenzoiltiourea, dan Phenobarbital Na sebagai bahan pembanding (Abbot Australia)

\section{Hewan Coba}

Dalam ppengamatan ini menggunakan mencit (Mus musculus) galur Balb C, jantan, dewasa berumur 2-3 bulan dengan berat badan 20-35 gram, tidak ada kelainan yang tampak pada bagian tubuh. Dua minggu sebelum perlakuan, dan mencit diadaptasikan pada ruangan tempat penelitian. Mencit dipuasakan selama 12 jam sebelum perlakuan dan setiap mencit hanya digunakan sekali (Levy et.al, 1989; Loscher and Lehmann, 1996).

alat Electroshock Seizure yaitu alat yang digunakan untuk melihat efek kejang mencit karena alat ini memberikan arus listrik sebesar $50 \mathrm{~mA}$ yang diinduksikan pada mata mencit, batang berputar (rotarod) yaitu alat yang berupa batang diputar dengan kecepatan 6 rpm untuk melihat lama waktu bertahan mencit pada batang berputar tersebut sebagai parameter dari efek neurotoksisitas, Neraca Analitik Sartorius 2472, disposible syringe Terumo $1 \mathrm{ml}$, timbangan mencit, alat pencatat waktu (stop watch), dan bak mencit.

\section{Identifikasi Efek Depresan SSP, Antikejang, dan Neurotoksisitas Identifikasi Efek Depresan SSP}

Identifikasi efek depresan SSP dilakukan dengan metode Barbiturat Sleeping Time dengan menggunakan mencit yang di kelompokkan menjadi 5 kelompok. Setiap kelompok terdiri dari 6 ekor, yaitu kelompok kontrol yang diberi suspensi CMC Na 0,5\% secara oral, kelompok pembanding diberi Phenobarbital Na 125 mg/kg BB secara oral, dan kelompok uji I sampai uji III berturutturut diberi senyawa 4-klorobenzoiltiourea dengan dosis $15 \mathrm{mg} / \mathrm{kgBB}, 45 \mathrm{mg} / \mathrm{kgBB}$, dan $75 \mathrm{mg} / \mathrm{kgBB}$ secara oral, maka setelah 30 menit (waktu aktivitas puncak senyawa uji) semua mencit kelompok uji diberi Phenobarbital $\mathrm{Na}$ $125 \mathrm{mg} / \mathrm{kg}$ BB secara oral. Parameter yang diamati adalah lama waktu tidur mencit mulai waktu mencit tidur (righting reflex negative) sampai mencit bangun (righting reflex positive). Data waktu tidur mencit dianalisa menggunakan anova one way.

\section{Identifikasi Efek Antikejang}

Identifikasi efek antikejang dilakukan dengan metode Maximum Electroshock Seizure (MES). Secara random mencit dibagi menjadi 5 kelompok yaitu 1 kelompok kontrol, 1 kelompok pembanding, dan 3 kelompok uji. Semua mencit diberi senyawa uji, suspensi CMC Na, dan Phenobarbital $\mathrm{Na}$ secara oral dengan dosis yang sama seperti pada pelaksanaan identifikasi efek depresan SSP, setelah 30 menit pemberian perlakuan, dan seluruh mencit dirangsang korneanya dengan arus listrik supramaksimal sebesar 50 $\mathrm{mA}$ selama 0,2 detik dengan alat penginduksi kejang (Electroshock Seizure). Pengamatan dilakukan terhadap pengaruh senyawa 4-klorobenzoiltiourea pada pola kejang/ seizure (tonik, klonik, dan tonik-klonik). Efek antikejang ditunjukkan dari kemampuan senyawa uji mengurangi atau mencegah terjadinya kejang (Turner, 1965; Thompson, 1990). Data waktu kejang mencit dianalisa menggunakan anova one way.

\section{Identifikasi Efek Neurotoksisitas}

Adanya gangguan neurologik dari senyawa uji ditentukan dengan menggunakan metode batang berputar. Secara random mencit dibagi menjadi 5 kelompok sesuai 
dengan identifikasi efek depresan. Semua mencit diberi senyawa uji, suspensi CMC $\mathrm{Na}$, dan phenobarbital Na secara oral dengan dosis yang sama seperti pada pelaksanaan identifikasi efek depresan SSP. Mencit dari tiap kelompok kemudian diletakkan pada alat batang berputar dengan kecepatan perputaran $6 \mathrm{rpm}$. Mencit normal dapat mempertahankan posisi pada batang berputar dalam waktu yang sangat lama. Adanya gangguan neurologi minimum misalnya ataksia, sedasi, dan hipereksitabilitas ditunjukkan oleh ketidakmampuan mencit mempertahankan posisinya dan jatuh dalam waktu 1 menit. Pengamatan dilakukan dalam waktu aktivitas puncak (30 menit) setelah pemberian perlakuan (Turner, 1965; Thompson, 1990). Data waktu bertahan mencit pada batang berputar dianalisa menggunakan anova one way.

\section{PEMBAHASAN Identifikasi Efek Depresan SSP}

Data mengenai waktu tidur mencit pada berbagai kelompok dan hasil statistiknya dapat dilihat pada tabel 1 dan 2, diagram batang rata-rata waktu tidur mencit dapat dilihat pada gambar 1 .

Tabel 1. Waktu Tidur Mencit Pada Berbagai Kelompok

\begin{tabular}{|c|c|c|c|c|c|}
\hline \multirow[b]{2}{*}{$\begin{array}{l}\text { Nomor } \\
\text { Mencit }\end{array}$} & \multicolumn{5}{|c|}{ Waktu Tidur Mencit (Menit) } \\
\hline & $\begin{array}{c}\text { CMC Na 0,5\% } \\
\text { (Kontrol) }\end{array}$ & $\begin{array}{c}\text { Fenobarbital Na } \\
125 \mathrm{mg} / \mathrm{kg} \mathrm{BB} \\
\text { (Pembanding) }\end{array}$ & $\begin{array}{c}\text { Senyawa } 15 \\
\text { mg/kg BB } \\
\text { (Uji I) }\end{array}$ & $\begin{array}{c}\text { Senyawa } 45 \\
\mathrm{mg} / \mathrm{kg} \mathrm{BB} \\
(\mathrm{Uji} \mathrm{II})\end{array}$ & $\begin{array}{c}\text { Senyawa } 75 \\
\text { mg/kg BB } \\
\text { (Uji III) }\end{array}$ \\
\hline 1 & 117,03 & 127,32 & 144,17 & 326,12 & 374,29 \\
\hline 2 & 119,16 & 126,99 & 148,26 & 324,39 & 375,12 \\
\hline 3 & 117,73 & 128,06 & 145,26 & 322,13 & 371,63 \\
\hline 4 & 116,22 & 125,65 & 152,71 & 323,75 & 372,46 \\
\hline 5 & 118,31 & 125,32 & 149,19 & 328,19 & 373,15 \\
\hline 6 & 116,65 & 127,56 & 149,67 & 328,29 & 373,65 \\
\hline Rata-rata \pm SD & $117.51 \pm 1.099$ & $126.81 \pm 1.0938$ & $148.21 \pm 3.1102$ & $325.48 \pm 2.4921$ & $373.38 \pm 1.2562$ \\
\hline
\end{tabular}

Diagram batang rata-rata waktu tidur mencit sebagai berikut:

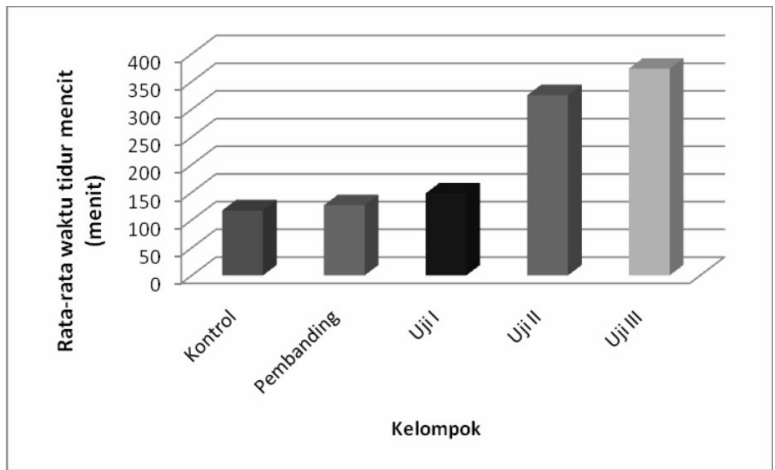

Gambar 2. Diagram Batang Rata-Rata Waktu Tidur Mencit Pada Berbagai Kelompok 
Tabel 2. Hasil Statistik Anova Waktu Tidur Mencit

\begin{tabular}{|l|l|l|}
\hline I (kelompok) & J (kelompok) & Signifikansi \\
\hline \multirow{4}{*}{ Kontrol } & Pembanding & 0,000 \\
\cline { 2 - 3 } & Uji I & 0,000 \\
\cline { 2 - 3 } & Uji II & 0,000 \\
\cline { 2 - 3 } & Uji III & 0,000 \\
\hline Pembanding & Uji I & 0,000 \\
\cline { 2 - 3 } & Uji II & 0,000 \\
\cline { 2 - 3 } & Uji III & 0,000 \\
\hline \multirow{2}{*}{ Uji I } & Uji II & 0,000 \\
\cline { 2 - 3 } & Uji III & 0,000 \\
\hline Uji II & Uji III & 0,000 \\
\hline
\end{tabular}

Hasil analisis statistik menunjukkan nilai signifikansi $0,000(<0,05)$ yang berarti bahwa ada perbedaan bermakna antara kelompok kontrol, kelompok pembanding, dan kelompok uji. Ini berarti waktu tidur mencit kelompok kontrol berbeda bermakna dengan kelompok pembanding dan uji di mana rata-rata waktu tidur kelompok uji lebih tinggi dibanding kelompok pembanding dan kontrol begitu juga waktu tidur mencit kelompok pembanding lebih tinggi dibanding kelompok kontrol.

Selanjutnya dilakukan perhitungan persentase perpanjangan waktu tidur mencit antara kelompok Phenobarbital $\mathrm{Na}$ dan kelompok uji untuk mengetahui apakah terdapat korelasi linier antara dosis senyawa 4-Klorobenzoiltiourea dengan perpanjangan waktu tidur mencit. Persentase perpanjangan waktu tidur mencit dihitung dari rumus :

Waktu tidur mencit (senyawa uji) -

$\frac{\text { Waktu tidur mencit (Phenobarbital Na) }}{\text { Waktu tidur mencit (Phenobarbital Na) }} \times 100 \%$

Tabel 3. Persentase Perpanjangan Waktu Tidur Mencit Pada Kelompok Uji I, II dan III

\begin{tabular}{|c|c|c|c|}
\hline \multirow{5}{*}{$\begin{array}{l}\text { Nomor } \\
\text { Mencit }\end{array}$} & \multicolumn{3}{|c|}{ Perpanjangan Waktu Tidur mencit (\%) } \\
\hline & Senyawa & Senyawa & Senyawa \\
\hline & 4-KBT 15 & 4-KBT 45 & 4-KBT 75 \\
\hline & $\mathrm{mg} / \mathrm{kg} \mathrm{BB}$ & $\mathrm{mg} / \mathrm{kg} \mathrm{BB}$ & $\mathrm{mg} / \mathrm{kg} \mathrm{BB}$ \\
\hline & (Uji I) & (Uji II) & (Uji III) \\
\hline 1 & 13.23 & 156.142 & 193.98 \\
\hline 2 & 16.75 & 155.44 & 196.39 \\
\hline 3 & 13.43 & 151.54 & 190.2 \\
\hline 4 & 21.54 & 157.66 & 196.42 \\
\hline 5 & 19.04 & 161.88 & 197.75 \\
\hline 6 & 17.33 & 157.36 & 192.92 \\
\hline Rata- & $16.89 \pm$ & $156.67 \pm$ & $194.44 \pm$ \\
\hline $\begin{array}{l}\text { rata } \pm \\
S D\end{array}$ & 3.2181 & 3.366 & 2.6968 \\
\hline
\end{tabular}

Berdasarkan data tabel 3 dilakukan analisa regresilinier untuk mengetahuiapakah ada hubungan linier antara peningkatan dosis senyawa 4-Klorobenzoiltiourea terhadap peningkatan waktu tidur mencit. Berikut ini adalah hasil regresi linier:

Tabel 4. Hasil Regresi Linier Kelompok Uji

\begin{tabular}{|c|c|c|c|}
\hline No. & $\begin{array}{c}\text { Dosis } \\
\text { Senyawa } \\
(\mathrm{mg} / \mathrm{kg} \\
\mathrm{BB})\end{array}$ & $\begin{array}{c}\text { Rata-rata } \\
\text { perpanjangan } \\
\text { waktu tidur } \\
\text { mencit (\%) }\end{array}$ & Nilai r \\
\hline 1. & 15 & 16.89 & \\
\hline 2. & 45 & 156.67 & \\
\hline 3. & 75 & 194.44 & \\
\hline \multicolumn{3}{|c|}{$\begin{array}{l}\text { Persamaan Regresi: -146.653 + } \\
15.7332 x\end{array}$} & 0.9491438942 \\
\hline
\end{tabular}

Hasil analisis menunjukkan bahwa $r_{\text {hitung }}$ $(0,949)>r_{\text {tabel }}(0,878)$, yang berarti bahwa ada korelasi linier yang signifikan antara dosis senyawa uji dan persentase perpanjangan waktu tidur mencit. Hal ini menunjukkan bahwa dosis senyawa uji makin meningkat maka waktu tidur mencitjugameningkat.Dilihatdaripersentaseratarata perpanjangan waktu tidur bahwa senyawa uji dengan dosis $75 \mathrm{mg} / \mathrm{kg}$ BB memberikan waktu tidur yang paling lama karena diduga senyawa uji sudah menduduki semua reseptor GABA $_{A}$ sehingga mampu memperpanjang pembukaan kanal $\mathrm{Cl}^{-}$, menyebabkan keadaan hiperpolarisasi, dan menekan transmisi sinaptik sehingga mengurangi rangsangan sel pada membran postsinaptik serta menyebabkan deaktivasi korteks serebral.

Berikut ini adalah grafik korelasi linier antara dosis senyawa uji dan persentase perpanjangan waktu tidur mencit.

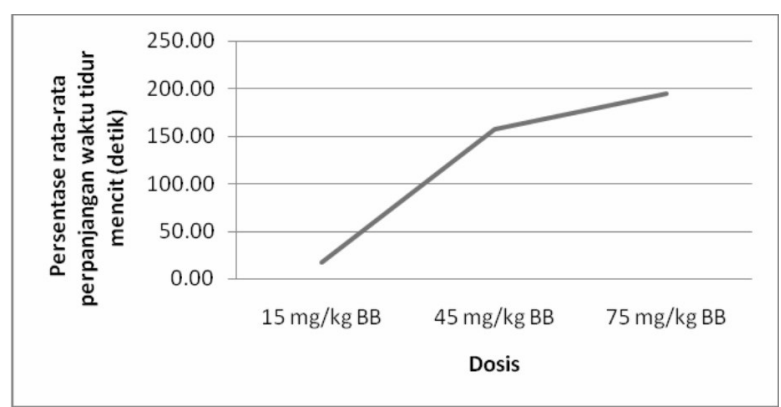

Gambar 3. Grafik Korelasi linier 


\section{AGUSLINA KIRTISHANTI, DINI KESUMA \& IDENTIFIKASI EFEK DEPRESAN SSP (SUSUNAN SARAF PUSAT), ANTIKEJANG DAN NEUROTOKSISITAS SENYAWA 4-KLOROBENZOILTIOUREA ...}

\section{Identifikasi Efek Antikejang}

Data waktu kejang mencit pada kelompok kontrol, pembanding dan uji dapat dilihat pada tabel 5 sampai tabel 9, dan diagram batang ratarata waktu kejang mencit dapat dilihat pada gambar 3. Hasil statistik anova waktu kejang mencit dapat dilihat pada tabel 10.

Tabel 5. Waktu Kejang Mencit Kelompok Kontrol

\begin{tabular}{|l|c|l|l|l|}
\hline \multirow{2}{*}{$\begin{array}{c}\text { No. } \\
\text { Mencit }\end{array}$} & \multicolumn{4}{|c|}{ Waktu Kejang Mencit (detik) } \\
\cline { 2 - 5 } & Tonik & Klonik & $\begin{array}{c}\text { Tonik- } \\
\text { Klonik }\end{array}$ & Total \\
\hline 1. & 17,40 & 02,61 & 07,68 & 27,69 \\
\hline 2. & 17,16 & - & 12,78 & 29,94 \\
\hline 3. & 18,20 & 02,48 & 07,96 & 28,64 \\
\hline 4. & 16,40 & 01,85 & 10,97 & 29,22 \\
\hline 5. & 17,52 & 01,47 & 09,79 & 28,78 \\
\hline 6. & 18,03 & 01,39 & 08,65 & 28,07 \\
\hline \multicolumn{4}{|l|}{ Rata-rata \pm SD } & $28,72 \pm 0,80$ \\
\hline
\end{tabular}

Tabel 6. Waktu Kejang Mencit Kelompok Pembanding

\begin{tabular}{|l|l|l|l|l|}
\hline \multirow{2}{*}{$\begin{array}{c}\text { No. } \\
\text { Mencit }\end{array}$} & \multicolumn{4}{|c|}{ Waktu Kejang Mencit (detik) } \\
\cline { 2 - 5 } & Tonik & Klonik & $\begin{array}{l}\text { Tonik- } \\
\text { klonik }\end{array}$ & Total \\
\hline 2. & - & 09,25 & 11,00 & 20,25 \\
\hline 3. & 04,52 & 03,19 & 11,53 & 19,24 \\
\hline 4. & - & 11,38 & 09,42 & 20,80 \\
\hline 6. & 08,36 & 02,85 & 07,45 & 18,66 \\
\hline 8. & - & 07,16 & 15,81 & 22,97 \\
\hline 10. & - & 07,16 & 13,73 & 20,89 \\
\hline \multicolumn{4}{|l|}{ Rata-rata \pm SD } & $20,47 \pm 1,51$ \\
\hline
\end{tabular}

Tabel 7. Waktu Kejang Mencit Kelompok Uji I (Dosis $15 \mathrm{mg} / \mathrm{kg}$ BB mencit)

\begin{tabular}{|l|c|l|l|l|}
\hline \multirow{2}{*}{$\begin{array}{c}\text { No. } \\
\text { Mencit }\end{array}$} & \multicolumn{4}{|c|}{ Waktu Kejang Mencit (detik) } \\
\cline { 2 - 5 } & Tonik & Klonik & $\begin{array}{l}\text { Tonik- } \\
\text { klonik }\end{array}$ & Total \\
\hline 1. & 15,08 & 01,22 & 06,52 & 22,82 \\
\hline 2. & 09,75 & 01,36 & 11,27 & 22,38 \\
\hline 3. & 14,26 & 01,75 & 05,34 & 21,35 \\
\hline 4. & 11.10 & 02.91 & 07,73 & 21,74 \\
\hline 5. & - & 08,45 & 14,41 & 22,86 \\
\hline 6. & 13,00 & 01,82 & 06,62 & 21,44 \\
\hline \multicolumn{4}{|l}{ Rata-rata \pm SD } & $22,10 \pm 0,68$ \\
\hline
\end{tabular}

Tabel 8. Waktu Kejang Mencit Kelompok Uji II (Dosis $45 \mathrm{mg} / \mathrm{kg}$ BB mencit)

\begin{tabular}{|c|c|c|c|c|}
\hline \multirow{2}{*}{$\begin{array}{l}\text { No. } \\
\text { Mencit }\end{array}$} & \multicolumn{4}{|c|}{ Waktu Kejang Mencit (detik) } \\
\hline & Tonik & Klonik & Tonik- & Total \\
\hline 1. & 12,39 & 02,19 & 08,97 & 23,55 \\
\hline 2. & 11,27 & 01,66 & 11,30 & 24,23 \\
\hline 3. & 12,49 & 01,57 & 08,99 & 23,05 \\
\hline 4. & 13,38 & 01,70 & 07,95 & 23,03 \\
\hline 5. & 12,16 & 01,55 & 08,61 & 22,32 \\
\hline 6. & 12,57 & 01,49 & 09,04 & 23,46 \\
\hline Rata-ra & $\pm \mathrm{SD}$ & & & $23,27 \pm 0,64$ \\
\hline
\end{tabular}

Tabel 9. Waktu Kejang Mencit Kelompok Uji III (Dosis $75 \mathrm{mg} / \mathrm{kg}$ BB mencit)

\begin{tabular}{|l|l|l|l|l|}
\hline \multirow{2}{*}{$\begin{array}{c}\text { No. } \\
\text { Mencit }\end{array}$} & \multicolumn{4}{|c|}{ Waktu Kejang Mencit (detik) } \\
\cline { 2 - 5 } & Tonik & Klonik & $\begin{array}{c}\text { Tonik- } \\
\text { klonik }\end{array}$ & Total \\
\hline 1. & 17,08 & 01,65 & 05,90 & 24,63 \\
\hline 2. & 15,01 & 01,91 & 05,65 & 22,57 \\
\hline 3. & 14,91 & 02,20 & 05,81 & 22,92 \\
\hline 4. & 15,76 & 01,64 & 06,68 & 24,08 \\
\hline 5. & 16,72 & 02,37 & 06,14 & 25,23 \\
\hline 6. & 14,65 & 02,13 & 08,36 & 25,14 \\
\hline \multicolumn{4}{|l|}{ Rata-rata \pm SD } & $24,10 \pm 1,13$ \\
\hline
\end{tabular}

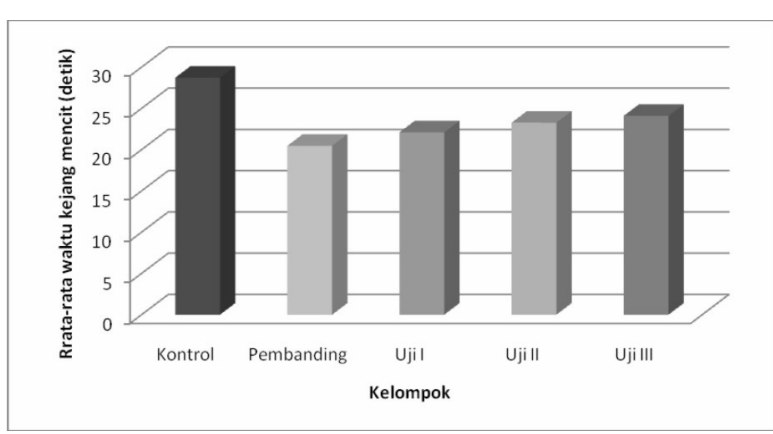

Gambar4.

Diagram Batang Rata-rata Waktu Kejang Mencit Pada Berbagai Kelompok

Tabel 10. Hasil Statistik Anova Waktu Kejang Mencit

\begin{tabular}{|l|l|l|}
\hline I (kelompok) & I (kelompok) & Signifikansi \\
\hline Kontrol & Pembanding & 0,000 \\
\cline { 2 - 3 } & Uji I & 0,000 \\
\cline { 2 - 3 } & Uji II & 0,000 \\
\cline { 2 - 3 } & Uji III & 0,000 \\
\hline \multirow{4}{*}{ Pembanding } & Uji I & 0,100 \\
\cline { 2 - 3 } & Uji II & 0,000 \\
\cline { 2 - 3 } & Uji III & 0,000 \\
\hline \multirow{2}{*}{ Uji I } & Uji II & 0,054 \\
\cline { 2 - 3 } & Uji III & 0,002 \\
\hline Uji II & Uji III & 0,170 \\
\hline
\end{tabular}

Dari hasil analisis statistik anova one way menunjukkan bahwa terdapat perbedaan bermakna antara kelompok kontrol dengan kelompok uji dan kelompok pembanding dengan nilai signifikansi 0,000 $(<0,05)$. Antara kelompok uji I dengan uji II tidak ada perbedaan yang bermakna (sig $=0,054)$ demikian juga antara kelompok uji II dengan uji III ( $\operatorname{sig}=0,170)$, tetapi ada perbedaan bermakna antara kelompok uji I dan uji III $(\operatorname{sig}=0,002)$. Bila dilihat dari rata-rata waktu kejang mencit, kelompok uji I dengan dosis 15 
$\mathrm{mg} / \mathrm{kg}$ BB memberikan waktu kejang yang paling singkat dibandingkan dengan kelompok uji II dan III.

\section{Identifikasi Efek Neurotoksisitas}

Data lama waktu bertahan mencit pada batang berputar untuk menunjukkan efek neurotoksisitas dan hasil statistiknya ditunjukkan pada tabel 11 dan 12.

Tabel 11. Lama Waktu Bertahan Mencit Pada Batang Berputar

\begin{tabular}{|c|c|c|c|c|c|}
\hline \multirow[b]{2}{*}{$\begin{array}{l}\text { Nomor } \\
\text { Mencit }\end{array}$} & \multicolumn{5}{|c|}{ Lama Waktu Bertahan Mencit (detik) } \\
\hline & $\begin{array}{c}\text { CMC Na } 0,5 \% \\
\text { (Kontrol) }\end{array}$ & $\begin{array}{c}\text { Phenobarbital Na } \\
125 \mathrm{mg} / \mathrm{kg} \mathrm{BB} \\
\text { (Pembanding) }\end{array}$ & $\begin{array}{c}\text { Senyawa } 15 \mathrm{mg} / \\
\mathrm{kg} \mathrm{BB} \\
(\mathrm{Uji} \mathrm{I}) \\
\end{array}$ & $\begin{array}{c}\text { Senyawa } 45 \\
\text { mg/kg BB } \\
(\text { Uji II })\end{array}$ & $\begin{array}{c}\text { Senyawa } 75 \\
\text { mg/kg BB } \\
\text { (Uji III) }\end{array}$ \\
\hline 1 & 38 & 27 & 17 & 15 & 26 \\
\hline 2 & 28 & 14 & 30 & 21 & 27 \\
\hline 3 & 34 & 18 & 30 & 14 & 36 \\
\hline 4 & 35 & 26 & 24 & 13 & 25 \\
\hline 5 & 24 & 26 & 26 & 16 & 35 \\
\hline 6 & 27 & 14 & 25 & 18 & 24 \\
\hline $\begin{array}{l}\text { Rata-rata } \\
\pm \text { SD }\end{array}$ & $31 \pm 5.4405$ & $20.83 \pm 6.2102$ & $25.33 \pm 4.8027$ & $16.16 \pm 2.9268$ & $28.83 \pm 5.2694$ \\
\hline
\end{tabular}

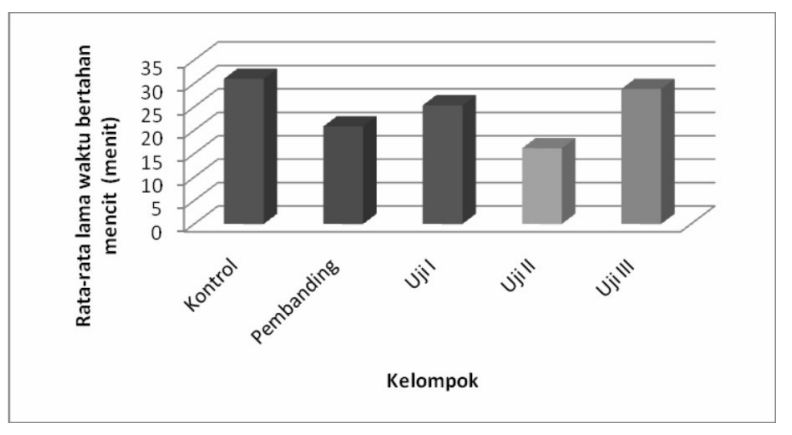

Gambar 5.

Diagram Batang Rata-rata Waktu Bertahan Mencit Pada Batang Berputar

Tabel 12. Hasil Statistik Anova Waktu Bertahan Mencit Pada Batang Berputar

\begin{tabular}{|l|l|l|}
\hline I (kelompok) & J (kelompok) & Signifikansi \\
\hline Kontrol & Pembanding & 0,002 \\
\cline { 2 - 3 } & Uji I & 0,063 \\
\cline { 2 - 3 } & Uji II & 0,000 \\
\cline { 2 - 3 } & Uji III & 0,464 \\
\hline Pembanding & Uji I & 0,135 \\
\cline { 2 - 3 } & Uji II & 0,122 \\
\cline { 2 - 3 } & Uji III & 0,011 \\
\hline \multirow{2}{*}{ Uji I } & Uji II & 0,004 \\
\cline { 2 - 3 } & Uji III & 0,241 \\
\hline Uji II & Uji III & 0,000 \\
\hline
\end{tabular}

Hasil statistik menunjukkan bahwa antara kelompok kontrol dengan kelompok uji I ( $\operatorname{sig}=0,063)$ dan uji III $(\operatorname{sig}=0,464)$ tidak ada perbedaan bermakna demikian juga antara kelompok pembanding dengan uji I $(\operatorname{sig}=0,135)$ dan uji II $(\operatorname{sig}=0,122)$. Ada perbedaan bermakna antara kelompok uji I dan uji II (sig $=0,004)$ serta antara uji II dan uji III ( $\operatorname{sig}=0,000)$. Tidak ada perbedaan bermakna antara uji I dengan uji III (sig = 0,241). Rata-rata waktu bertahan mencit pada batang berputar berturut-turut mulai dari waktu yang paling singkat adalah kelompok uji II (16,16 detik), pembanding (20,83 detik), uji I (25,33 detik), uji III (28,83 detik) dan kelompok kontrol (31 detik). Rata-rata waktu bertahan mencit pada batang berputar untuk kelompok pembanding (20,83 detik) berada di antara rata-rata waktu bertahan mencit antara kelompok uji II dan uji I (16,16 - 25,33 detik). Melihat hasil analisis tersebut diketahui bahwa kelompok uji II dengan dosis $45 \mathrm{mg} /$ kg BB memberikan waktu bertahan pada batang berputar paling singkat.

Senyawa 4-Klorobenzoiltiourea merupakan modifikasi dari senyawa benzoiltiourea yang disintesis dengan cara asilasi senyawa tiourea dengan 4-klorobenzoil klorida. Senyawa benzoiltiourea memiliki aktivitas penekan sistem saraf pusat karena strukturnya yang mirip dengan senyawa golongan barbiturat. Turunan barbiturat bekerja dengan menekan transmisi sinaptik 
pada sistem pengaktifan retikula di otak dengan cara mengubah permeabilitas membran sel sehingga mengurangi rangsangan sel postsinaptik dan menyebabkan deaktivasi korteks serebral (Siswandono, 2000). Senyawa 4-Klorobenzoiltiourea memiliki sifat lipofilik dan elektronik yang lebih tinggi dibandingkan dengan senyawa induknya benzoiltiourea. Secara teoritis, senyawa benzoiltiourea mempunyai nilai lipofilitas $(\log P)=1,12$. Pemasukkan atom klorida $(\mathrm{Cl})$ pada cincin aromatis akan meningkatkan lipofilitas (log P) menjadi 1,68 sedangkan nilai log P optimal obat penekan sistem saraf pusat $=2$ (Kesuma, 2004).

Peningkatan sifat lipofilik memungkinkan obat akan diabsorpsi dengan baik dalam membran biologis sehingga jumlah obat yang berinteraksi dengan reseptor lebih banyak. Penambahan gugus klorida (Cl) yang bersifat sebagai penarik elektron dapat memperkuat ikatan obat dan reseptor, sehingga dapat menghasilkan aktivitas yang lebih besar. Senyawa 4-klorobenzoiltiourea mampu berpenetrasi ke otak dan diduga dapat mengikat reseptor barbiturat pada reseptor $\mathrm{GABA}_{\mathrm{A}}$ karena kemiripan strukturnya dengan senyawa barbiturat (mengandung gugus ureida) sehingga mampu memperpanjang pembukaan kanal $\mathrm{Cl}^{-}$menyebabkan keadaan hiperpolarisasi dan menekan transmisi sinaptik sehingga mengurangi rangsangan sel pada membran post-sinaptik dan menyebabkan deaktivasi korteks serebral. Oleh karena itu, efek yang terlihat dari hasil penelitianini bahwa senyawa 4-klorobenzoiltiourea dapat memberikan efek depresan SSP, efek antikejang, dan penurunan aktivitas motorik.

Senyawa pembanding yang digunakan adalah Phenobarbital Na. Phenobarbital $\mathrm{Na}$ termasuk turunan barbiturat dengan masa kerja panjang yang digunakan sebagai sedatif, hipnotik, dan antikejang. Obat diabsorpsi dalam saluran cerna $\pm 80 \%$, kadar puncak obat dalam darah dicapai dalam waktu 6-18 jam setelah pemberian oral, dengan waktu paruh 72-96 jam. Awal kerja obat untuk Phenobarbital $\mathrm{Na}$ adalah 30-60 menit (Caroline NL, 2006; Katzung et al, 2002). Phenobarbital dapat menekan sistem saraf pusat melalui ikatan dengan reseptor GABA, menghalangi aliran impuls saraf di sistem saraf pusat (Schull, 2009).

Hewan coba yang digunakan dalam penelitian ini adalah mencit putih jantan (Mus musculus) galur Balb C karena lebih peka terhadap obat yang bekerja pada sistem saraf pusat. Mencit yang digunakan harus naîf yang belum pernah mendapat perlakuan apapun karena mencit yang telah mengenali wadah atau tempat eksperimen menunjukkan perilaku yang berbeda dengan mencit yang masih naif.

Pada uji efek antikejang digunakan alat Electroshock seizure sebagai penginduksi kejang mencit. Induksi yang diberikan berupa arus listrik sebesar $50 \mathrm{~mA}$ selama 0,2 detik. Arus tersebut dipilih karena dapat menghasilkan kejang yang maksimal pada mencit dengan kemungkinan letal sekecil mungkin. Elektrode tumpul pada alat Electroshock disentuhkan pada kornea mata mencit karena mata berhubungan dengan saraf kranial kedua dan ketiga pada susunan saraf pusat sehingga dapat merangsang letupan listrik abnormal pada serebral dengan cepat. Impuls listrik dihantarkan menuju organ-organ motorik sehingga memicu terjadinya aktivitas motorik yang abnormal dan menimbulkan kejang. Kejang yang ditimbulkan setelah induksi listrik berupa kejang tonik, klonik, dan tonik-klonik. Kejang tonik ditandai dengan hentakan atau dorongan kuat dari anggota badan ke depan dan belakang anggota tubuh dengan keadaan tubuh mencit kaku, kejang klonik ditandai dengan gerakan memutar kaki depan, dan belakang dari mencit ke arah dalam yang sangat berlebihan, sedangkan kejang tonikklonik ditandai dengan menghentak secara berulang-ulang dari kaki depan dan belakang dengan keadaan tubuh merebah ke samping (Thompson, 1990). 
Uji neurotoksisitas adalah suatu uji yang mengamati adanya gangguan motorik pada mencit. Uji tersebut dilakukan dengan menggunakan alat rotarod. Prinsipnya adalah hewan percobaan yaitu mencit diletakkan pada alat rotarod dengan kecepatan putaran 6 rpm, kemudian diamati berapa lama mencit tersebut dapat bertahan pada batang putar. Mencit normal dapat mempertahankan posisi pada batang berputar dalam waktu yang lama (Basori, 2003).

Berdasarkan hasil pengamatan di atas, maka perlu dilakukan pengembangan untuk penelitian selanjutnya berupa uji toksisitas akut, subkronis, dan kronis dari senyawa 4 klorobenzoiltiourea.

\section{SIMPULAN}

$\begin{array}{ccr}\text { Berdasarkan hasil penelitian } \\ \text { dapat disimpulkan } \\ \text { 4-klorobenzoiltiourea } & \text { memberikan efek }\end{array}$ depressan SSP, efek antikejang, dan neurotoksisitas. Efek depresan SSP dengan metode Barbiturat Sleeping Time paling baik pada dosis $75 \mathrm{mg} / \mathrm{kg}$ BB, efek antikejang paling baik diberikan pada dosis $15 \mathrm{mg} / \mathrm{kg}$ $\mathrm{BB}$, dan efek neurotoksisitas paling baik pada dosis $45 \mathrm{mg} / \mathrm{kg} \mathrm{BB}$.

\section{DAFTAR PUSTAKA}

Basori A, Sri P, 2003, Identifikasi Efek Antiseizure Dan Efek Neurotoksisitas Dari Ekstrak Fraxinus Griffithii Clarke, Surabaya: Laboratorium Farmakologi Fakultas Kedokteran Unair.

Basuki SA, 2006, Sintesis N-(2,4-Diklorobenzoil) Tiourea dan Uji Aktivitas Penekan Sistem Saraf Pusat pada Mencit (Mus musculus), Tesis tidak dipublikasikan, Suarabaya: Fakultas Farmasi Universitas Airlangga.

Burger A, 1983, "A Guide to the Chemical Basis of Drug Design", New York, Chichester, Brisbane, Toronto, Singapore: John Wiley \& Sons, 163164.
Caroline NL, 2006, “Nancy Caroline's Emergency Care in the Streets", $6^{\text {th }}$ edition, USA: Jones and Bartlett Publishers International.

Fessenden RJ, Fessenden SJ, 1990, Kimia Organik, Edisi Ketiga, Jilid I dan II, Terjemah Pudjaatmaka AH., Jakarta : Penerbit Airlangga.

Ganiswara, G. Sulistia, 1995, Farmakologi dan Terapi, Edisi IV, Fakultas Kedokteran UI, Ui Press, Jakarta, hal. 124-143, 769.

Guyton, Arthur C, MD, 2000, Buku Ajar Fisiologi Kedokteran, Terj. Ken Ariata Tengadi, DKK, Edisi ketujuh, Bagian dua, Jakarta: Penerbit Buku Kedokteran EGC, hlm. 249, 408-41.

Hansch C, Steward, AR, Anderson, SM, Bentley D, 1968, "The Parabolic Dependence of Drug Action Upon lipophilic Character as Releaved by a Study of Hypnotics", J.Med.Chem, 11:1.

Hansch C, Leo A, 1979, "Substituen Constants for Correlation Analysis in Chemistry and Biology", New York: Wiley Interscience, pp 3, 18, 63.

Hyde RM, 1975, “Relationships Between The Biological and Physicochemical Properties of Series Compounds", J med.Chem, 18 : 231-233

Katzung BG, 2001, Farmakologi Dasar dan Klinik, Terjemahan Bagian Farmakologi Kedokteran Universitas Airlangga, Edisi Pertama Bahasa Indonesia, Jakarta: Penerbit Salemba Medika.

Kesuma D, 2004, Modifikasi Struktur Benzoiltiourea dan Uji Aktivitas Penekan SSP, tesis tidak dipublikasikan, Fakultas Farmasi Universitas Airlangga, Surabaya

Korolkovas A, 1988, "Essentials Of Medicinal Chemistry", $2^{\text {nd }}$ ed., New York, Chichester, Brisbane, Tronto, Singapore: John Willey dan Sons, 590-597, 692-697. 
AGUSLINA KIRTISHANTI, DINI KESUMA \& IDENTIFIKASI EFEK DEPRESAN SSP (SUSUNAN SARAF PUSAT), ANTIKEJANG DAN NEUROTOKSISITAS SENYAWA 4-KLOROBENZOILTIOUREA ...

Levine, Ruth R, 1983, “Pharmacology: Drug Action and Reaction", 3 rdedition, United States of America: Little Brown Company, pp.483-488.

Levy RH, Dreifuss FE, Mattson RH, Meldrum BS, Penry JK, 1989, “Antiepileptic Drugs", New York : Raven Press, pp 91.

Lien EJ, 1969, “The Use of Subtituent Constant and Regression Analysis in The Study of Struktur-Activity Relationship", Am.J. Pharm. Educ, 33: 368.

Lien EJ, 1987, "SAR : Side Effect and Drug Design", New York, Basel: Marcel Dekker Inc,pp, 102-111.

Loscher W, Lehmann H, 1996, “L-Deprenyl (Selegiline) Exerts Anticonvulsant Effects against Different Seizure Types in Mice", J.Pharmaco.Exp. Ther, 277, 2: 1410-1417.

Mutschler, Ernst, 1991, Dinamika Obat, Edisi 5, Alih Bahasa : Widianto B dan B. Mathilda, Institut Teknologi Bandung Press, Bandung, hal 107-168.

Rekker RF, Mannhold R, 1992, "Calculation of Drug Lipophilicity”, VCH Weinheim, pp 5-20.

Schefler WC, 1987, Statistika untuk Biologi, Farmasi, Kedokteran dan Ilmu yang Bertautan, Terjemahan Suroso, Terbitan kedua, Bandung: Penerbit ITB, hlm. 93-102.

Schull PD, 2009, "I.V Drug Handbook", Mc Graw-Hill, New York.

Siswandono, 1998, Sintesis Senyawa Baru Turunan Asil dan Benzoil-N-Urea untuk
Optimasi Aktivitas penekan Sistem Sarat Pusat, Laporan Riset Unggulan Terpadu VI (1), hal 8-36.

Siswandono, Soekardjo B, 1998, PrinsipPrinsip Rancangan Obat, Surabaya; Airlangga University Press.

Siswandono, 1999, Modifikasi Struktur dan Hubungan Struktur Aktivitas Senyawa Baru Turunan Benzoilurea, Disertasi , Program Pascasarjana universitas Airlangga, Surabaya.

Siswandono, Soekardjo B, 2000, Kimia Medisinal, Surabaya: Airlangga University Press.

Steel RGD, Torrie JH, 1981, "Principles and Procedure of Statistics, A Biometrical Approach", $2^{\text {nd }}$ ed., Auckland-Tokyo: McGraw Hill International Book Company, pp524-543.

Topliss JG, 1972, “Utilization of Operational Schemes for Analog Synthesis in Drug Design", J.Med.Chem., 15: 1006-1011.

Turner RA, 1965, "Screening Methods in Pharmacology", Academic Press, New York, London.

Thompson, EB, 1990, “Drug Bioscreening, Drug Evaluation Technique In Pharmacology", Department of Pharmacodynamics, College Pharmacy, The University of Illinois, New York, pp 3-11, 49-50.

Vida, Julius A, 1995, Depresan Sistem Saraf Pusat : Sedativa - Hipnotika, dalam Foye, WO., Prinsip-Prinsip Kimia Medisinal, Terj. Rasyid, R, Jilid I, Edisi Kedua, Yogyakarta: Gajah Mada University Press, hlm. 280, 293-294, 299-230. 